\title{
Research on Upgrading of Chinese Automobile Industry Value Chain
}

\author{
Jun-Qing Liu ${ }^{1, a}$ \\ ${ }^{1}$ Shandong University of Finance and Economics, Shungeng road 40, Shizhongqu, Jinan, \\ Shandong, China \\ a1075571844@qq.com
}

Keywords: Automobile industry, Global value chain, Industrial upgrading.

\begin{abstract}
The paper is to deal with the upgrading of China's automobile industry value chain. The automotive industry is a pillar industry of China. But comparing with international brands, China's auto industry always has the problem that being at low added value. Therefore, researching on upgrading of automotive industry value chain has important practical significance. The methodology based on the data of 2008-2013 of Chinese automobile industry developing to explore current situation and barriers that hinder the development of the automobile industry. As a result the paper try figure out solutions to improve automobile industry's developing.
\end{abstract}

\section{Introduction}

With the deepening of economic globalization, global value chain extending is increasingly being used as industrial upgrading and governance model. Automobile industry as capital and technology-intensive industry is the pillar industry of the national economy because of its long industrial chain, wide industry association and high added value. After half a century of development, China's auto industry's production and marketing is the largest in the world and with the further enhance of urbanization, the demand for the market will massive. However, due to the lack of independent brands and weak core technology, as well as the strong presence of large foreign multinational companies, China's auto industry has been at the end of the global value chain and low value-added manufacturing sectors. In order to achieve the transformation and upgrading of the automobile industry, we should select some efforts to increase investment in research and brand-building efforts. And designing right industrial development policies to guide the direction of development of the automobile industry is what we should do. Only in this way can we achieve rapid and sustainable development of China's automobile industry.

\section{Related Theoretical Basis about the Upgrading of Value Chain of Auto Industry}

1) Related concepts of the value chain

The concept of the value chain that developed originally by Professor Michael Porter in 1985 is the sum of the link with its business organization, management of production, sales of products and services related to the behaviors of a variety of value-added. Each act constitutes a link of the value chain. While every aspect of the value chain are related to other areas, but a link to what extent can affect the value creation activities of other sectors depend on its position in the value chain. Porter's "value chain" theory reveals that the competition between enterprises, not just the competition of one link, but competition in the entire value chain. Comprehensive competitiveness of the entire value chain decides competitiveness of enterprises. The difference between the value chain competitors is a key source of competitive advantage. The difference between the value chains is a key source of competitive advantage.

2) Content and upgrading of the industrial chain

With economic globalization and the deepening division of labour within the industry, the various aspects of the industry value chain is broken down and transferred to different countries and regions. Founding their positions in the value chain becomes the focus of the business currently. Poon (2004) believes that the industrial upgrading is the transfer processes of economic role that transferring successfully from the production of low-value labor-intensive to produce higher value products of 
technology-intensive products. But no matter from what angle, which in common is this: industrial upgrading is the evolution of the process that technology from low level, low added value state to high-tech, high value-added state .

Acer Group founder Mr. Shi was proposed to describe the image of the value chain: the smile curve (Figure 1). Both ends of the curve are upward. In the industrial chain, more value reflected ends, design and sales, while in the middle part of manufacturing value added to a minimum. The low value generated by the manufacturing stage, while high value added in $\mathrm{R} \& \mathrm{D}$ and marketing, so the future direction should be the two ends of the smile curve, which is on the left side to strengthen research and create intellectual property rights, strengthen customer-oriented marketing and service at the right. Automobile industry chain includes four aspects: first, product design, development; the second is the procurement of spare parts; the third is car manufacturers; the fourth is the sales and service. Profits created by Automotive Financial services are growing in the international market.

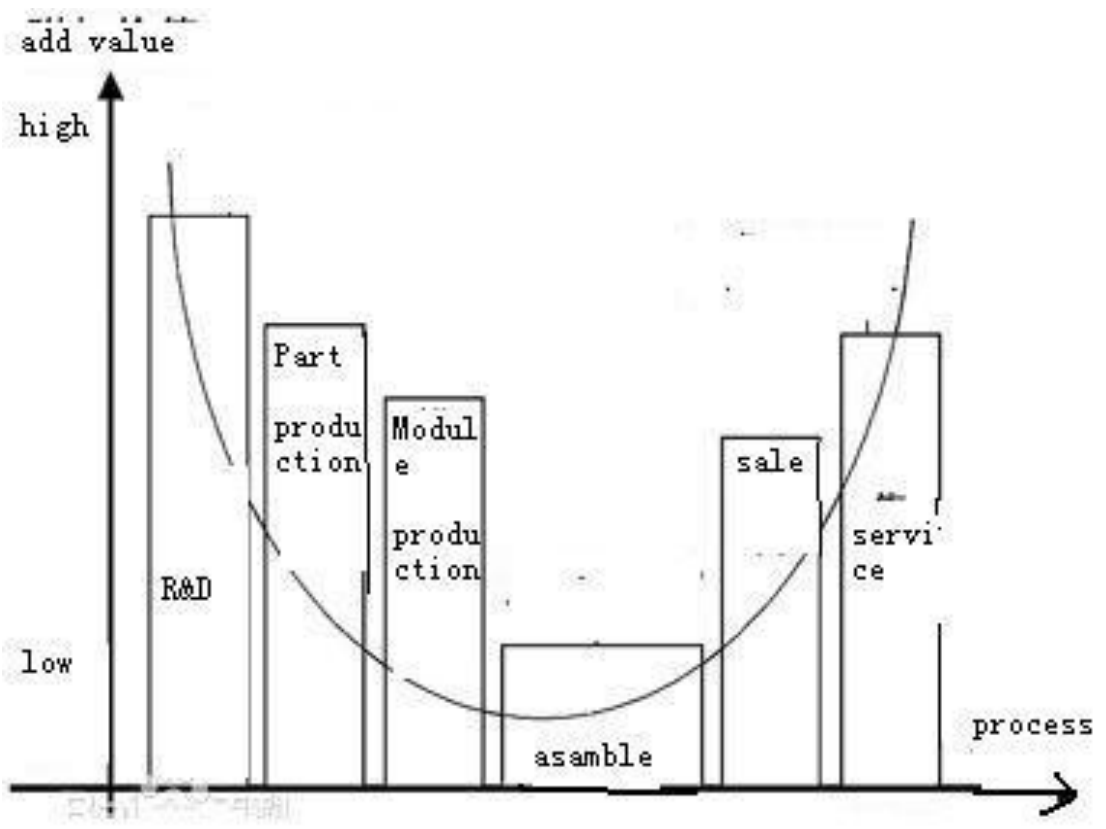

Fig. 1 Smile Curve

\section{Analysis of the Automobile Industry Development Situation}

1) The scale of automobile industry currently

In 2013, the national automobile production is 22.1168 million and 21.9841 million, which is up nearly $14.8 \%$ and $14.8 \%$ over the last year. The national automobile production has been the NO.1 for five years. The annual changes of Chinese automobile industry sales can refer to figure 3 . In 2003 , the total imports and exports of our country automobile industry is 135.7 billion, which is up $6.1 \%$ than last year. Imports are $\$ 81.89$ billion, which is up 5.5\% than last year; Exports is $\$ 53.8$ billion, which is up 7\% than last year. In 2013, the total industry outputs of Chinese important industries are 603.321 billion yuan, which is up $25.14 \%$ than last year. The total industrial output is 2.510489 trillion yuan, which is up $19.26 \%$ than last year. Thus, Chinese market size and market potential is big, and the development of Chinese industry is vigorous. (Data Sources: China Association of Automobile Manufacturers)

But the auto industry contains many advanced technologies. Our industries are faced with many difficulties, such as the exports of many famous foreign industries. The Chinese industries do not own the advanced technologies. Besides, the form of foreign after-sales service is a complete set, what's worse, Chinese productions are often refused by foreign countries. In addition, Chinese labor costs and raw material prices have been rising, and the industry average profit spaces have been shrinking. It is harmful to cultivate our core competitiveness. As a result, the development of automobile industry is still faced with many difficulties. 


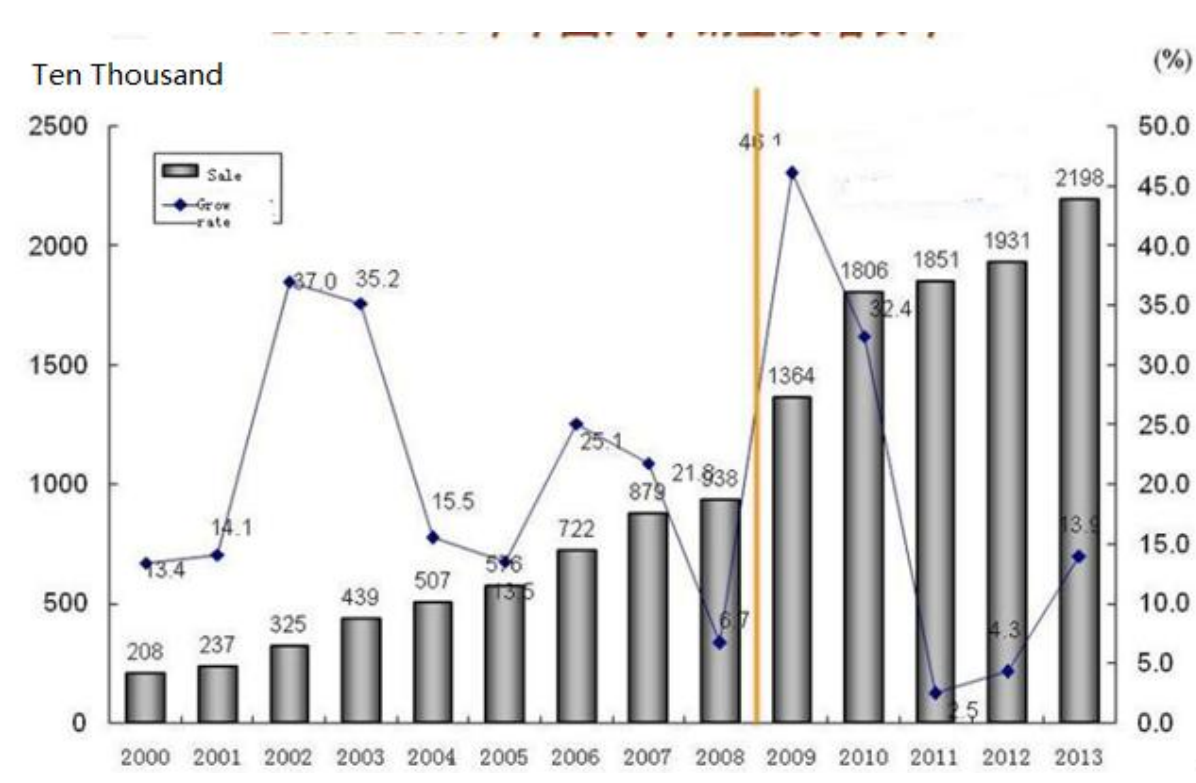

Fig. 2

2) R\&D investment scale of automobile enterprise

In recent years, with the development of China's automobile industry, a profound understanding in the technology gap between themselves and the leading international standard for the automotive industry is being acknowledged. Therefore R\&D investment has been growing. But the growth rate of $25.9 \%$ in 2008 dropped to $7.9 \%$ in 2012. And the investment of R\&D account for relatively small proportion of the main business income. (See Table 1). (Data Sources: China Association of Automobile Manufacturers)

Tab. 1 China automobile industrial R\&D depending

\begin{tabular}{|l|l|l|l|}
\hline Year & $\begin{array}{l}\text { R\&D depending (Hundred } \\
\text { million) }\end{array}$ & Growth rate(\%) & $\begin{array}{l}\text { The proportion of main } \\
\text { business income(\%) }\end{array}$ \\
\hline 2008 & 388.7 & 25.9 & 2.07 \\
\hline 2009 & 460.6 & 18.5 & 1.93 \\
\hline 2010 & 498.8 & 8.3 & 1.62 \\
\hline 2011 & 548 & 9.8 & 1.63 \\
\hline 2012 & 591.3 & 7.9 & 1.63 \\
\hline
\end{tabular}

Tab. 2 Comparison of 5 countries' R\&D depending of automobile industrial

\begin{tabular}{|l|l|l|l|l|}
\hline \multirow{2}{*}{ Nation } & \multicolumn{2}{|l|}{ Vehicle manufacturers } & \multicolumn{2}{l|}{ Parts manufacturers } \\
\cline { 2 - 5 } & $\begin{array}{l}\text { R\&D depending } \\
\text { (million } \\
\text { pounds) }\end{array}$ & $\begin{array}{l}\text { Percentage } \\
\text { sales (\%) }\end{array}$ & $\begin{array}{l}\text { R\&D depending } \\
\text { (million pounds) }\end{array}$ & Percentage of sales (\%) \\
\hline Japan & 14939.75 & 4.5 & 3859.9 & 5.7 \\
\hline America & 10491.44 & 4.9 & 1177.16 & 3.1 \\
\hline Germany & 7319.41 & 5.5 & 5852.74 & 8.2 \\
\hline France & 5679.26 & 4.7 & 1000.45 & 5.0 \\
\hline
\end{tabular}

Under the institution that lowing R\&D investment and declining grow rate in our country, the automotive industry R\&D spending in Europe and other developed countries has always maintained a large proportion, as shown in Table 2. According to statistics, nearly five years, the R\&D investment in the Japanese automotive industry giants will remain at $5 \%$ of its sales; according to the top 1000 of R\&D investment published by British Ministry of Business, Innovation and Science in 2011 (including 20 automobile companies, 49 auto parts enterprises), only one automobile company was included (number 19), R\&D investment $£ 1,478,100$, accounting for $2.1 \%$ of sales, for the same period Toyota $2 \%$ of the total R \& D investment. None of the auto parts enterprises 
was included. (Data Sources: China Association of Automobile Manufacturers)

3) Brand construction of automobile industry

In the early stages of vehicle development, in order to rapidly improve the level of development of China's automobile industry, especially cars, China's automotive market is open to foreign capital. Domestic auto companies embedded multinational auto company's production processes through joint ventures cooperative mode. Using of technology spillover and learning effects, upgrading from the low part of the value chain to high-value links. Such policies largely accelerate growth of China's automobile industry. However, this policy makes local enterprises fell behind foreign companies in brand building and market share. Table 3 is a 2013 passenger car market share of other faculties' comparison.

The figure shows that the passenger car market in the country, the independent brand's market share is about $40 \%$. China's high-end passenger car market is still firmly occupied by foreign brands. The main reason for this situation is the lack of $R \& D$ investment. Core products and core technology is the company's vitality. Therefore, China's auto industry needs hard efforts in the product development, research and made high-tech car, not just low-cost means of transport. (Data Sources : China Association of Automobile Manufacturers)

Tab. 3 Passenger car market share

\begin{tabular}{|l|r|r|r|r|r|r|r|}
\hline & \multicolumn{1}{|l|}{ China } & \multicolumn{1}{l}{ Germany } & \multicolumn{1}{l}{ Japan } & \multicolumn{1}{l|}{ America } & \multicolumn{1}{l|}{ Korea } & France & \multicolumn{1}{l|}{ Others } \\
\hline Jan & 43.3 & 19 & 13 & 11.8 & 9.5 & 3.2 & 0.2 \\
\hline Feb & 43 & 19.9 & 11.9 & 12.1 & 9.5 & 3.5 & 0.1 \\
\hline Mar & 43.4 & 18.3 & 15 & 11.8 & 8.2 & 3.1 & 0.2 \\
\hline Apr & 39.6 & 19.3 & 16.1 & 12.5 & 9.1 & 3.1 & 0.3 \\
\hline May & 39.4 & 19.3 & 16 & 12.4 & 9.3 & 3.3 & 0.3 \\
\hline June & 37.5 & 20.6 & 16.5 & 12.7 & 9.4 & 3 & 0.3 \\
\hline July & 35.2 & 21.4 & 17.6 & 13.6 & 9 & 3 & 0.2 \\
\hline Aug & 38 & 21.7 & 15.2 & 13.1 & 9 & 2.9 & 0.1 \\
\hline Sept & 38.2 & 19.3 & 17.5 & 13 & 8.5 & 2.9 & 0.6 \\
\hline Oct & 40.5 & 18.7 & 17 & 12.8 & 7.8 & 2.9 & 0.3 \\
\hline Nov & 40.5 & 15.6 & 19.2 & 12.7 & 8.6 & 3.2 & 0.2 \\
\hline Dec & 42.8 & 15 & 19.7 & 11.1 & 8.2 & 2.9 & 0.3 \\
\hline
\end{tabular}

\section{Suggestions to Promote China's Automobile Industry Upgrading}

1) Targeted to choose related link to enter the value chain

Similar with factor endowments theory, companies should find its comparative advantage, targeted to choose to enter the value chain of related links. Thus, according to the actual situation of China's enterprises, they can choose an upgrade path from the following aspects.

Vehicle manufacturers can start from the third world automotive design and production. Due to the lack of infrastructure in these countries as well as people's consumption level is low, inexpensive and practical needs are there main market features. Chinese enterprises can increase research and development in this aspect and produce marketable products. Excellent parts enterprises select to enter the first-tier suppliers. Large multinational car assemblers like g parts enterprises who possess high product standard and sub-suppliers management experience. Thereby increasing the degree of standardization of spare parts, following leading companies within the industry, they can quickly achieve industrial upgrading. General repair parts business from cut and components market. By imitating the outstanding leader of product technology, they can enhance the value of their product. Enterprises which make inferior cars can select automotive marketing and sales or service. In the automotive marketing and sales or service, they can take advantages in terms of marketing network and localization to achieve the smile curve to the right upgrading.

2) Strengthening $R \& D$ investment, enhance independent innovation capability

Add value to fundamentally dependent on technological upgrading, which is the fundamental policy of industrial upgrading. The capital and talent is a major factor. Because of the low end of the 
value chain of production, low profits, and financial strength is weak, it should develop multilateral cooperation to solve the funding problem, enhance research and development funds in the proportion of total profits. Because technology has strong positive externalities, the state should do this to provide greater credit and tax incentives to reduce corporate pressure. In addition, companies can choose and universities, research institutes to establish relations of cooperation, both to improve the conversion rate of scientific research but also to solve the technical problems of enterprises. Enhance the level of cooperation with foreign actively acquire large multinational automotive company's technology spillover, through the introduction of technology and innovation, strategic absorbing process is also implemented by incremental innovation to radical innovation development path.

3) The government implements a proactive industrial policy

First, adhere to the strategy that "energy-saving and new energy vehicles". In the future investment direction of the car industry should be based on energy conservation, environmental protection and new energy, which not only meet the requirements of China's economic development, but also the direction of the current global automotive value chain upgrading. Therefore, effective policies should be made for independent research and development of new energy vehicles and technology innovation.

Second, creating a good environment for competition and accelerating the automobile industry restructuring. One characteristic of China's automobile industry is small but complete and fragmented nature. This situation is largely caused by the region where there are different levels of trade protectionism. Therefore, the Government should give full play to the power of government to balance the interests of all regions, and avoid the unfair distribution of benefits and hinder cross-recombination behaviours. Government use industrial policy, like tax policy, welfare subsidies and other economic instruments to support the reasonable merger and reorganization of enterprises.

Third, intensify policy power to support foreign trade and foreign investment. With China's rising labor costs and the opening of emerging market countries, the advantage of labor resources is disappearing while the auto industry is a typical capital and technology-intensive industries. Therefore supporting auto exports will benefit a lot for improving the export trade structure. In addition, foreign direct investment will help enterprises to find the most favourable production base to make the product more marketable, break trade barriers, increase market share.

\section{Reference}

[1] China Association of Automobile Manufacturers, China Automotive Industry Yearbook editorial department, China Automotive Industry Yearbook[M],2011,2013.

[2]Zhang Xiangyang, Research on upgrading of the value chain of the industry [J], Foreign Economics and Management, 2005(5).

[3]Zhou Yi, Nie Ming, Analysis of China's auto industry upgrade path Global Value Chain[J], Technology Progress and Policy,2009(7).

[4]Yang Dongjin, Liu Renhuai, GVC autonomous mode: reliable upgrade path to China's auto industry[J], Management of Technology,2010(2).

[5]Duan Wenjuan, Nie Ming, Zhang Ming, China Automotive Industry Global Value Chain Upgrading study[J],2006(2).

[6]Wang Jing, Upgrading of the value chain of China's auto industry[D],Shandong University.

[7]Ding Zhingqing, Approach and Strategy of China's automobile industry to upgrade proposal[J], Social Science Journal,2009(8). 